\title{
New species and new or interesting records of click-beetles from Iran and Iraq (Coleoptera, Elateridae)
}

\author{
Giuseppe Platia \& Ivo Gudenzi
}

Platia, G. \& Gudenzi, I. 1999: New species and new or interesting records of click-beetles from Iran and Iraq (Coleoptera, Elateridae). - Entomologica Fennica 10: 117-125.

This paper provides new records and descriptions of eight new species of clickbeetles (Coleoptera, Elateridae) from Iran and Iraq. The species are grouped according to tribes and the new taxa belong to the genera Calais Castelnau, Idotarmonides Agajew, Melanotus Eschscholtz, Craspedostethus Schwarz, Dicronychus Brullé; new names are proposed for two species of Cardiophorus Eschscholtz (preoccupied).

\section{Platia Giuseppe, Via Molino Vecchio, 21, 47030 Gatteo (Forli') Italia} Ivo Gudenzi, Via Corbari, 32, 47100 Forli', Italia

Received 25 April 1997, accepted 1 June 1998

\section{Introduction}

Amongst numerous indetermined click-beetles collected in Iran and Iraq and recently sent for study by Dr. Hans Silfverberg of the Zoological Museum of Helsinki University, we have found, in addition to common species, already recorded for the two countries, some other unrecorded or uncommon and eight undescribed species, belonging to different genera. Particularly interesting is the discovery of a new species of Calais Castelnau, a genus rich in taxa in Tropical Africa and Oriental Asia but poorly represented in this geographic area. Also the fourth new species of the genus Idotarmonides Agajew, 1985 (established to accommodate Betarmon anatolicus Candèze) is considered to be very interesting. The elaterid fauna of the two Asian countries is still not well known; the number of the species actually known, separately described over the years by different authors, seems to be very poor considering the extent of the territories and the papers published till now. This new contribution einriches the number of the known species and farther increases are expected when the political situation of the two countries becomes amenable to faunistic researchs.

\section{Material and methods}

Measurements of entire body. The length is measured along the midline from the anterior margin of frons to apex of elytra; the width is measured at the widest part.

Measurements of pronotum. The length is measured along the midline; the width includes also the hind angles.

The male genitalia are drawing in dorsal view. All the holotypes of the new species are preserved in the Zoological Museum of Helsinki.

\section{The species}

Tribe Agrypnini Candèze, 1857

Lacon unicolor (Candèze, 1874). - 2 exx. Iran, without exact locality, F. Brandt.

(Figs. 7, 15, 21). 
Tribe Hemirhipini Candèze, 1857

\section{Calais brandti n. sp.}

(Figs. 16, 17).

Description. Female. Entirely dark-ferruginous, blackish only around the scutellum and along the elytral suture; covered with narrow and elongate scales of variable colour, whitish to yellowish sometimes darkened, more or less regularly placed and not forming particular patterns.

Head with frons feebly depressed from vertex, not carinate in front; punctures broad, nearly contiguous. Antennae (Fig. 16) short, just reaching the middle of pronotum, serrated from third segment; second small, subconical, wider than long; third triangular; fourth to tenth quadrangular, as long as wide; eleventh with subparallel sides and clearly narrowed before the apex.

Pronotum as long as wide, strongly convex on the disk, abruptly sloping at base, more gradually at sides; sides arcuate with the greatest width at middle and at apex of posterior angles; distinctly sinuate before the posterior angles, the later acuminate, strongly divergent, with prominent and short carina subparallel to the lateral border, in dorsal view entirely apparent; punctures regular on all the surface, simple, of variable diameters with very short and shiny intervals, denser at sides.

Scutellum tongue-shaped, gradually sloping, convex in the first two thirds of its length, feebly concave toward apex, densely punctured. Elytra 2,35 times longer than pronotum and 2 times longer than wide, suboval, with greatest width near middle; striae well marked from base to apex, punctured only at sides; interstriae subconvex around the basal declivity, the third is more convex, flat behind the scutellum toward the apex, densely punctured.

Tarsal articles simple, decreasing regularly in length; claw simple with two robust setae at base.

Last abdominal visible segment moderately rounded with long and dense hairs just curved at apex.

Material examined. Holotype o - Iran, without exact locality, 6.VI., leg. F. Brandt (Zool. Mus. Helsinki).

Size. Length $\mathrm{mm}$ 17.8; width $\mathrm{mm}$ 5.6.

Male. Unknown.

Comparative remarks. Separated from Calais persicus Chassain, 1991 essentially by the less dense and thickened scales covering the body not forming particular pattern, the posterior angles of pronotum more acuminate and divergent, the scutellum without median longitudinal raised line. Tribe Oophorini Gistel, 1856

Aeoloides heydeni (Reitter, 1891). - 6 exx. Iran: Khorasan, Deh Shor, 25 km N Tabas, 17.IV.1994 R. Linnavuori.

Described from Turkmenistan. New record for Iran.

Tribe Synaptini Gistel, 1856

Adrastus dolini Wellschmied, 1978. - 2 exx. Iran: Gilan, Asalem, 2.VII.1996, R. Linnavuori; Gilan, Rasht, VI-VII.1996, R. Linnavuori.

Described from Caucasus. New record for Iran.

Tribe Ampedini Gistel, 1856

Ampedus sinuatus Germar, 1844. - 1 ex. Iran: Gilan, Darreh Dashdt, 27-28.V.1995, R. Linnavuori.

Distribution. Central and South Europe, Turkey, Caucasus. New record for Iran.

Tribe Pomachiliini Candèze, 1859

\section{Idotarmonides bicolor $\mathbf{n}$. sp.}

( Figs. 8, 19).

Description. Male. Entirely ferruginous with head, central part of prosternum, metathorax and abdomen blackish; covered with yellow-fulvous pubescence.

Frons convex on vertex, feebly impressed anteriorly with margin obsolete and confused with clypeus, suprantennal carinae nearly touching the anterior margin; punctures broader, denser and umbilicate in anterior half; finer and sparser in posterior half. Antennae exceeding more than two segments past the posterior angles of pronotum, serrate from third article; second as long as wide, third-tenth triangular, longer than wide.

Pronotum as long as wide, strongly and regularly convex, nearly vertically sloping at sides, more gradually at base; sides regularly arcuate, 
just sinuate before the posterior angles, the later divergent, acuminate, only with a vestige of carina; lateral border feeble but complete, in dorsal view visible only in posterior third; punctures on the disk deep, of variable diameters, more or less clearly umbilicate, with intervals on average larger than own diameters, shiny or just shagreened, at sides denser, clearly umbilicate with shagreened intervals; base without lateral incisions.

Scutellum longer than wide, very obliquous, with sides strongly narrowing from base to apex, convex, slightly punctured. Elytra 2.7 times longer than pronotum and 2.6 times longer than wide; sides subparallel for about two thirds of its length, then narrowing toward apex; striae well marked and punctured from base to apical third where they are less clear and superficial.

Tarsal segments simple and regularly decreasing in length; claws simple.

Material examined. Holotype o - Iraq: Irbil, nr. Salahuddin, 12.VI.1980, R. Linnavuori (Zool. Mus. Helsinki).

Male genitalia. As in fig. 8.

Size. Length mm 6; width mm 1,5.

Female. Unknown.

Comparative remarks. Fourth known species of the genus Idotarmonides Agajew, distinguishable by characteristic body colour and sparser punctures on disk of pronotum.

Tribe Melanotini Candèze, 1859

Melanotus fulvus Reitter,1891. - 18 exx. Iraq: Rawah Al-Hadr, 6.V.1991, R. Linnavuori.

Described from Turkestan. New record for Iraq.

\section{Melanotus dichroides n. sp.}

(Figs. 3, 11,14, 18).

Description. Male. Upper body side shiny, blackish with ferruginous shadings on sides and posterior angles of pronotum; antennae, legs and body underside ferruginous with blackish shadings; covered with yellow fulvous pubescence.

Frons convex on vertex, flat anteriorly with margin directed downwards, in the middle nearly obsolete and not projecting above clypeus; punctures broad, umbilicate, with short, shiny inter- vals. Antennae (fig. 14) reaching or just surpassing posterior angles of pronotum; second article as long as broad, third subconical, a little longer than second, together as long as fourth; fourthtenth triangular, longer than wide; eleventh ellipsoidal, longer than penultimate.

Pronotum just wider than long, more or less convex on the disk, abruptly declivous at base with a trace of median longitudinal depression; at sides more gradually sloping; lateral border complete, in dorsal view visible only in the posterior half; sides arcuate, from middle or just behind the middle strongly narrowing forward; more or less sinuate before the posterior angles, the latter acute, at apex convergent, with carina subparallel to lateral margin; punctures deep, more or less clearly umbilicate, of variable diameter and density; intervals on disk smaller than own diameters, at sides broader, denser and nearly contiguous.

Scutellum rectangular, flat, densely punctured. Elytra on average 2.7 times longer than pronotum and 2.3 times longer than wide; sides subparallel for two thirds of its length, then narrowing towards apex; striae well marked from base to apex, punctured; interstriae flat, with dense and finer punctures.

Prosternal process immediately bent behind the procoxal cavities.

Female. Body more parallel and larger; antennae shorter not reaching posterior angles of pronotum. Copulatrix bursa sclerified as in fig. 11.

Material examined. Holotype o - Iran: Gilan, Rasht, VI-VIII.1996, R. Linnavuori. (Zool. Mus. Helsinki). 9 Paratypes ( $6 o^{\star} o^{\star}$ and 3 우 으 same data as holotype (Zool. Mus. Helsinki; Platia coll.).

Male genitalia. As in fig. 3 .

Size. Length mm 10-12; width $\mathrm{mm}$ 3.1-3.8.

Comparative remarks. Similar to $M$. dichrous (Erichson) but distinct since second and third antennal joints are together as long as the fourth.

\section{Melanotus iranicus n. sp.}

(Figs. 1, 2, 13, 22).

Description. Male. Entirely ferruginous, blackish only around scutellum, base of elytra and sides of pronotum; covered with long, partially erect, yellow pubescence. 

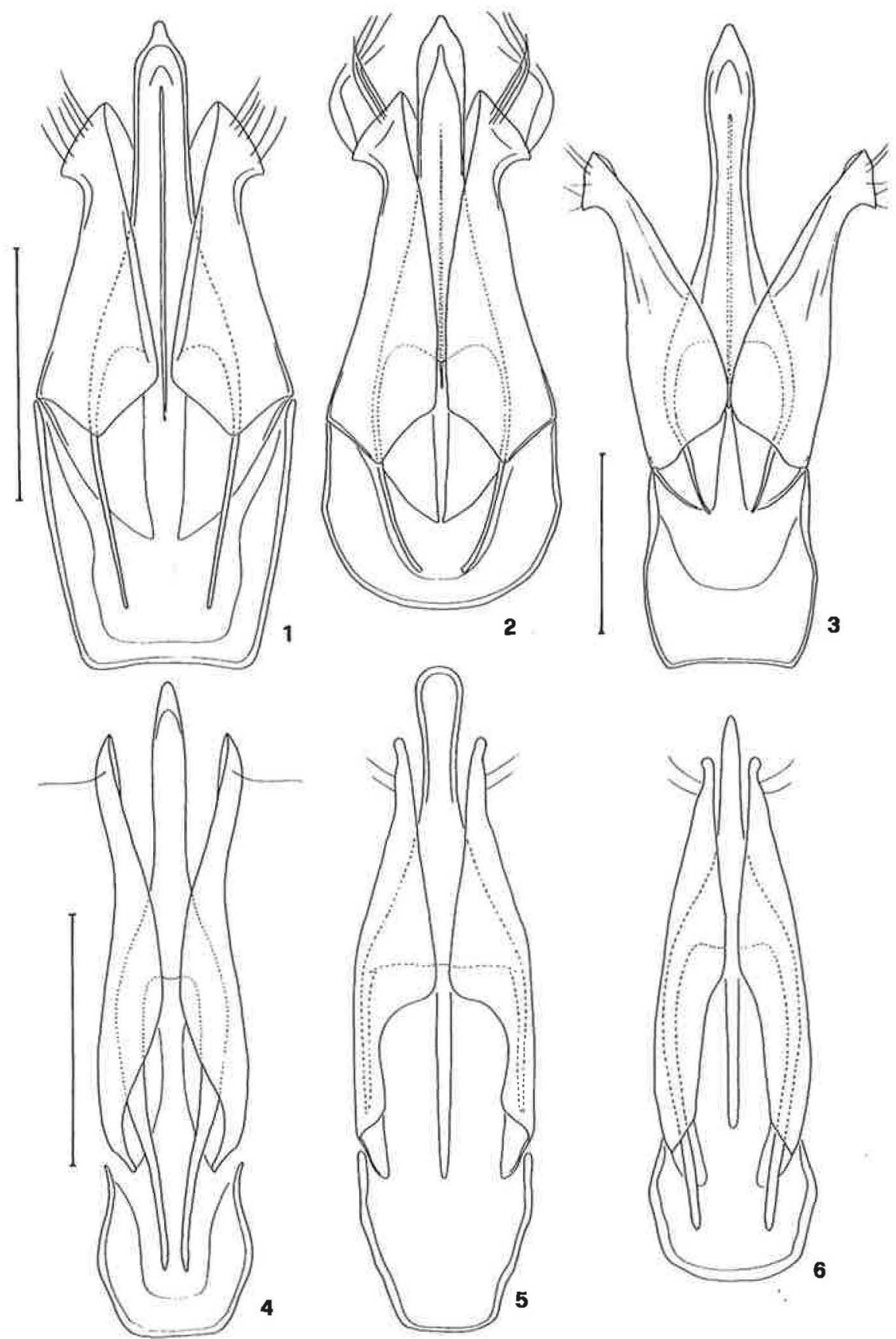

Figs. 1-6. Male genitalia in dorsal view. 1-3 (scale: 0,5 mm). 1-2. Melanotus iranicus $\mathrm{n}$. sp. (Holotype, Paratype); 3 . Melanotus dichroides n. sp. (Holotype); 4-6 (scale: 0,25 mm). 4. Craspedostethus schusteri (Schwarz) (Lectotype); 5. Craspedostethus iranicus n. sp. (Holotype); 6. Craspedostethus linnavuorii n. sp. (Holotype). 
Frons flat with anterior margin feebly arcuate, directed downward, barely projecting above clypeus; punctures broad, umbilicate, nearly contiguous. Antennae (fig. 13) exceeding two segments past posterior angles of pronotum, serrate from fourth; second subcylindrical, third subconical, subequal in length, together shorter than fourth; fourth-tenth triangular, longer than wide; eleventh largely ellipsoidal, longer than tenth.

Pronotum just wider than long, moderately convex, with lateral margin complete and nearly completely visible in dorsal view; sides more or less regularly arcuate, sinuate before posterior angles, the latter convergent at apex, with short carina, subparallel to lateral margin; punctures on disk umbilicate, variable in diameter, with small and shiny intervals, at base finer, at sides broader, nearly contiguous.

Scutellum tongue-shaped, flat, punctured. Elytra on average 3.4 times longer than pronotum and 2.7 times longer than wide; sides subparallel, only narrowing towards apex; striae well marked, deeply punctured particularly at sides; interstriae flat to subconvex with finer punctures.

Prosternal process immediately bent behind the procoxal cavities.

Material examined. Holotype $\sigma^{\star}-$ Iran: Teheran, Keredj, F. Brandt (Zool. Mus. Helsinki). Paratype o - Iran: without exact locality, 23.III., F. Brandt (Zool. Mus. Helsinki).

Male genitalia. With a degree of variability as in fig. 1 (Holotype) and fig. 2 (Paratype). 3.1 .

Size. Length mm 10.6-11.8; width mm 2.7-

Female. Unknown.

Comparative remarks. Similar in general shape and colour to M. turkmenicus Dolin \& Atamuradov, but distinct on the basis of the more robust body and longer antennae with second and third antennal joints together shorter than fourth.

Subfamily Negastriinae Nakane \& Kishii, 1956

Quasimus minutissimus (Germar, 1817). - 20 exx.: Iran: Gilan, Darreh Dasht, 27.28.V.1995, R. Linnavuori; Gilan, Masuleh, 26.VI.1995, R. Linnavuori; Gilan, Lounak, 30.V.1995, R. Linnavuori.

Distribution. Europe, Turkey, Caucasus,
Sibiria. New record for Iran.

Tribe Cardiophorini Candèze, 1860

*Cardiophorus neoalienus $\mathrm{n}$. name for $C$. alienus Dolin, 1969 (Armenia; Azerbaijan)(preoccupied by C. alienus Szombathy, 1910 (Java) 2 exx. Iraq: Diyala nr. Darbandikhan, 13.V.1980, R. Linnavuori.

New record for Iraq.

\section{Craspedostethus iranicus n. sp. (Fig. 5).}

Description. Male. Entirely yellow ferruginous, darker at sides of body; covered with dense, yellow golden pubescence.

Head with frons convex, anterior margin regularly arcuate, feebly thickened; puncturation double, finer and denser punctures mixed with sparser and larger punctures. Antennae reaching posterior angles of pronotum; second segment sub-clindrical, slightly longer than wide, third subconical, just longer than second and shorter than third; fourth-tenth triangular, longer than wide; eleventh subellipsoidal, a little longer than the penultimate.

Pronotum as long as wide, moderately and regularly convex; sides arcuate with greatest width at middle, feebly sinuate before posterior angles, the latter short and truncate at apex; lateral margin short, not reaching the middle of pronotum; puncturation double, finer and denser punctures mixed with irregular, bigger, about twice the double of the diameter, punctures.

Scutellum heart-shaped, as long as wide, narrowly emarginate toward middle of base, feebly concave and very densely punctured. Elytra 2.5 times longer than pronotum and 1.9 times longer than wide, suboval, with greatest width at middle; striae regularly marked and superficially punctured; interstriae flat, densely punctured.

Claws simple.

Material examined. Holotype $\sigma^{\top}$ - Iran: Evin nr. Teheran, 14-18.VII.1995, leg. R. Linnavuori (Zool. Mus. Helsinki).

Male genitalia (Fig. 5). With median lobe longer than paramera and dilated apically.

Female. Unknown.

Size. Length mm 4.8; width mm 1.6. 
Comparative remarks. Similar to $C$. linnavuorii $\mathrm{n}$. sp. from Iraq but distinguishable by the shorter antennae, pronotum as long as wide, male genitalia with median lobe apically dilated.

\section{Craspedostethus linnavuorii n. sp.}

(Fig. 6).

Description. Male. Entirely yellow ferruginous covered with dense, yellow golden pubescence.

Head with frons feebly convex, anterior margin narrowly arcuate, puncturation made of finer and denser punctures mixed with irregular and bigger punctures. Antennae exceeding about one segment on posterior angles of pronotum; second article subcylindrical, third subconical, subequal in length, together just longer than fourth; fourthtenth triangular, longer than wide (the fith is longer); eleventh subellipsoidal, a little longer than the penultimate.

Pronotum 1.25 times broader than long, moderately and regularly convex; sides arcuate with greatest width at middle, slightly sinuate before posterior angles, the latter truncate at apex; lateral margin reaching middle of pronotum; puncturation composed of finer and denser punctures mixed with more or less irregular and larger ones.

Scutellum heart-shaped, as long as wide, feebly emarginate in the middle of base, slightly concave and finely punctured. Elytra 2.7 times longer than pronotum and 1.9 times longer than wide, suboval, sides with greatest width at middle; striae well marked and punctured; interstriae flat or feebly convex, with finer punctures.

Claws simple.

Material examined. Holotype $\sigma$ - Iraq: Ninawa, Al Qosh, 25.VIII.1980, leg. R. Linnavuori. (Zool. Mus. Helsinki). 5 Paratypes ( $4 \sigma^{\circ} \sigma^{\circ}$ + 1 ) - same data as Holotype; Rawah-Al Hadr, 6.V.1981, leg. R. Linnavuori (Zool. Mus. Helsinki; Platia coll.).

Male genitalia (Fig. 6). With median lobe longer than paramera, apically acuminate.

Female. Body larger, more parallel, antennae shorter not reaching the posterior angles of pronotum.

Size. Length $\mathrm{mm}$ 3.5-5; width $\mathrm{mm}$ 1.2-1.7.

Comparative remarks. Destinguishable from C. schusteri (Schwarz, 1897) comb. n., described from Bagdad, by the longer antennae with fourthtenth segments more serrate and the different apex of male genital paramera (Fig. 4).

\section{Dicronychus fusivittatus n. sp. (Figs. 9, 20).}

Description. Male. Head, pronotum, sides of scutellum red-ferruginous with blackish shadings to nearly entirely blackish; elytra lighter, yellowish with blackish areas, more or less fusiform vitta along the suture; antennae, legs and underbody yellow-ferruginous; covered with dense yellow golden pubescence.

Head with frons convex on vertex, slightly at anterior margin; punctures simple, nearly contiguous, of the same size. Antennae reaching posterior angles of pronotum, feebly serrated from third segment; second article subconical, shorter than third, third-tenth subtriangular, longer than wide; eleventh with subparallel sides for two thirds of its length then narrowing towards apex.

Pronotum as long as wide, regularly convex; sides arcuate with greatest width at middle, sinuate before posterior angles, the latter truncate at apex and briefly carinate; puncturation uniform, punctures simple, nearly contiguous and of the same size, but some irregular and sparser punctures bigger; suture of lateral margins elongate and two thirds the length of pronotum.

Scutellum heart-shaped, emarginate at base in the middle, as long as wide or a little longer, concave in the disk. Elytra suboval, 2.5 times longer than pronotum and 2 times longer than wide; striae well marked and deeply punctured, only more superficial near apex; interstriae flat to subconvex with very fine punctures.

Claws well dilated in the first half.

Material examined. Holotype $\sigma$ - Iraq: Rawah - Al Hadr, 6.V.1981, R. Linnavuori (Zool. Mus. Helsinki). 2 Paratypes $\sigma^{\pi} \sigma^{*}$ - same data as holotype and Baghdad, V-VI.1981, R. Linnavuori (Zool. Mus. Helsinki; Platia coll.).

Male. Genitalia as in fig. 9.

Female. Unknown.

Size. Length mm 6.3-7.1; width mm 1.9-2.

Comparative remarks. On the basis of its distinct colour body the species is easily separated from other known species of the region. 


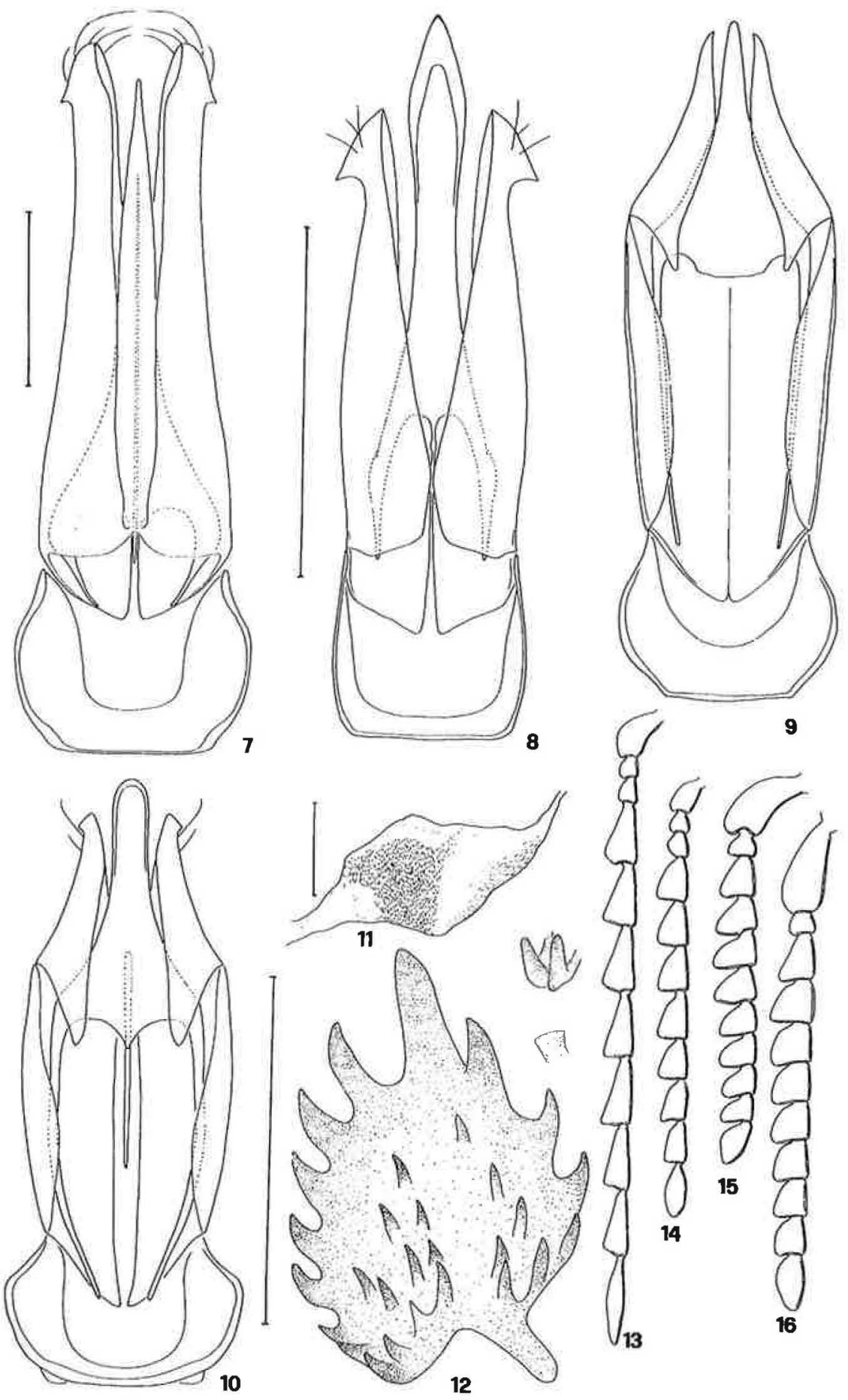

Figs. 7-16. Male genitalia in dorsal view; copulatrix bursa plates; antenna. 7-12 (scale: 0,5 mm). 7. Lacon unicolor (Candèze); 8. Idotarmonides bicolor n. sp. (Holotype); 9. Dicronychus fusivittatus n. sp. (Holotype); 10. Dicronychus mesopotamicus n. sp. (Holotype). 11. Melanotus dichroides n. sp. (Paratype); 12. Dicronychus mesopotamicus n. sp. (Paratype). 13. Melanotus iranicus n. sp. (Holotype); 14. Melanotus dichroides n. sp. (Holotype); 15. Lacon unicolor (Candèze); 16. Calais brandti n. sp. (Holotype). 


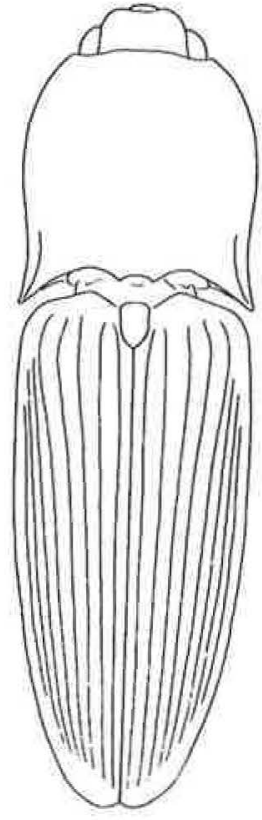

17

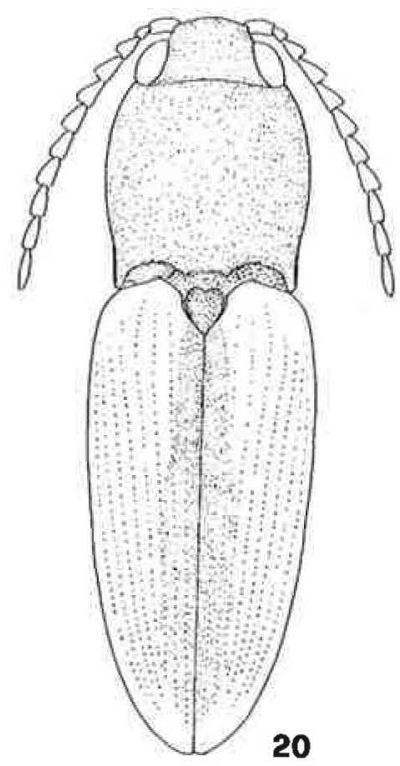

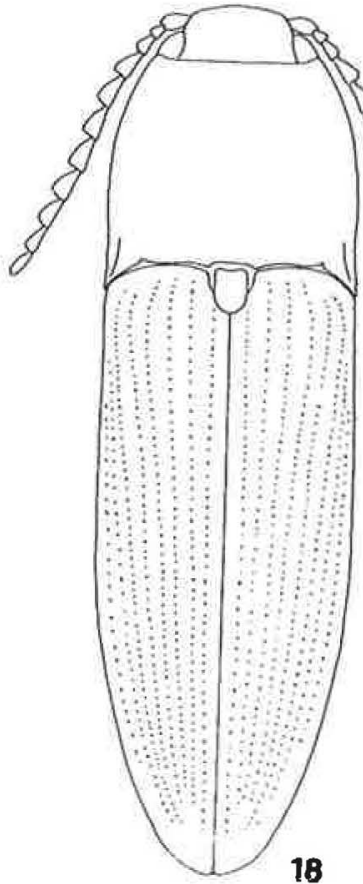

18

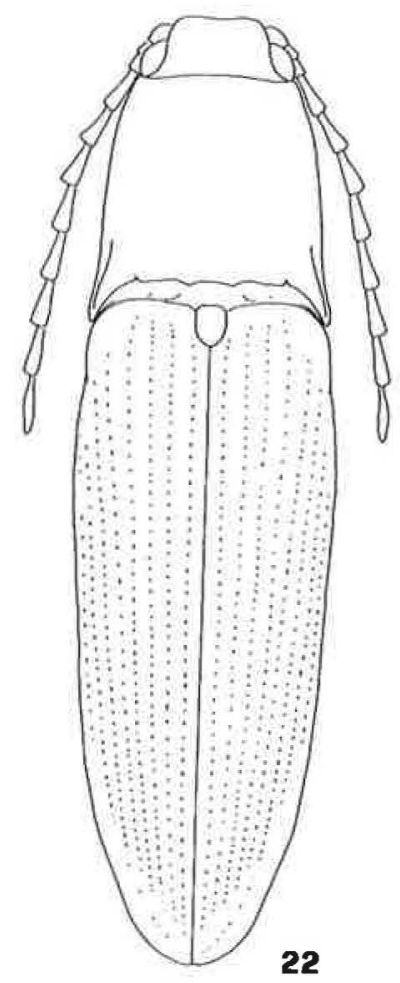

Figs. 17-22. Habitus. 17. Calais brandti $\mathrm{n}$. sp.; 18. Melanotus dichroides n. sp.; 19. Idotarmonides bicolor n. sp.; 20. Dicronychus fusivittatus n. sp.; 21. Lacon unicolor (Candèze); 22. Melanotus iranicus n. sp. (Holotype). 
Dicronychus mesopotamicus n. sp. (Figs. 10, 12).

Description. Male. Entirely red, ferruginous with blackish shadings around the scutellum and along the elytral suture; covered with dense yellow fulvous pubescence.

Head with frons flat, anterior margin subarcuate, directed downwards, punctures dense, more or less of the same size, nearly contiguous. Antennae short, not reaching the posterior angles of pronotum, feebly serrated from third segment; second article subconical, longer than wide; third subtriangular, longer than second and the following; fourth-tenth triangular, longer than wide; eleventh subellipsoidal.

Pronotum as long as broad, strongly and regularly convex, at sides and base abruptly sloping; sides regularly arcuate with greatest width at middle, feebly sinuate before posterior angles, the latter with a very short carina; punctures of double size, finer and denser punctures regularly mixed with bigger and sparser punctures; suture of lateral margins elongate, extending two thirds the length of pronotum.

Scutellum heart-shaped, as long as wide, emarginate at base in the middle, feebly concave on the disk. Elytra 2.1 times longer than pronotum and 1.9 times longer than wide, oval, sides with greatest width in the middle; striae regularly marked from base to apex, deeply punctured; interstriae subconvex, very finely punctured.

Posterior half of prosternum with impressed $\mathrm{v}$-shaped lines departing from middle of prosternal process and running subparallel to pronoto- sternal sutures.

Claws very feebly dilated in anterior half.

Material examined. Holotype o -- Iraq: anNajaf, Shabakah-Waqisah, 5.IV.1981, R. Linnavuori (Zool. Mus. Helsinki). Paratype o same data as holotype.

Male genitalia. As in Fig. 10.

Female. Very similar to male with a little short antennae. Copulatrix bursa sclerified as in Fig.12.

Size. Length $\mathrm{mm}$ 6.5-7; width $\mathrm{mm}$ 2.2-2.3.

Comparative remarks. Similar to $D$. extinctus (Erichson) but distinguishable by a series of characters such as darker colour, sides of pronotum with greatest width at middle, suture of the lateral margins shorter.

* We suggest also that C. arnoldii Dolin, 1960 be named Cardiophorus neoarnoldii n. name (Ukraina) due to preoccupation by $C$. arnoldii Leseigneur, 1958 (South Rhodesia).

\section{References}

Candèze, E. 1874: Révision de la monographie des Elatérides. - Mémoires de la Société royale des Sciences de Liège (2) (4): $226 \mathrm{pp}$.

Chassain, J. 1991: Description de deux espèces paléarctiques nouvelles du genre Calais Castelnau (Coleoptera, Elateridae). - Nouvelle Revue Entomologie (N.S.), 8 (2): 211-215.

Dolin, V. G. 1969: Einige neue Elateriden aus dem Krim, Kaukasus und Tjanj-Schanj Gebirge (Col. Elateridae). — Beiträge zur Entomologie 19 (1-2):123-135.

Dolin, V. G. \& Atamuradov, Ch. J. 1994: Click beetles (Elateridae) of the Turkmenistan. - Schmalhausen Institute of Zoology, Kiew: 175 pp. 